\title{
ISTRAŽIVANJE ZADOVOLJSTVA ZAPOSLENIH U SEKTORU PROIZVODNJE I IT SEKTORU
}

\section{RESEARCH OF EMPOYEE SATISFACTION IN THE MANUFACTURING SECTOR AND IT SECTOR}

\author{
Jelena Lukić, Fakultet tehničkih nauka, Novi Sad
}

\section{Oblast - INŽENJERSKI MENADŽMENT}

Kratak sadržaj - Za potrebe ovog rada, izvršeno je istraživanje zadovoljstva zaposlenih u proizvodnji kao $i$ zaposlenih u IT sektoru. Rezultati istraživanja pokazuju da su zaposleni u najvećem broju zadovoljni celokupnom organizacijom, ali da u pojedinim segmentima postoji nezadovoljstvo. $\mathrm{Za}$ istraživanje je korišćen standardizovani anketni upitnik.

Ključne reči: Zaposleni, organizacija, zadovoljstvo poslom, menadžment ljudskih resursa

\begin{abstract}
For the purposes of this paper, a survey of the satisfaction of employees in production as well as employess in the IT sector was conducted.The results of the survey show that most empoyees are satisfied with he overall organization, but in some segments there is a dissatisfaction. A standardized survey questionnaire was used for the research.
\end{abstract}

Keywords: Staff, Organization, Work satisfaction, Human Resource Management

\section{UVOD}

Praćenje zadovoljstva zaposlenih važno je kako za organizaciju tako i za radnike pojedinačno. Zadovoljstvo poslom je najvažniji stav među svim stavovima zaposlenih, kod pojedinca on izaziva kognitivne, afektivne $\mathrm{i}$ evalutivne reakcije. Zadovoljstvo poslom predstvalja složen stav koji uključuje određene pretpostavke i verovanja o tom poslu (kognitivna komponenta), osećanja prema poslu (afektivna komponenta) i ocenu posla (evalutivna komponenta).

Zadovoljstvo poslom se u kompanijama najčešće ispituje, što je i opravdano, jer samo je zadovoljan radnik i dobar radnik. Odnosno uspeh organizacije nije moguće postići sa nezadovoljnim radnicima. Zadovoljstvo poslom se razlikuje od osobe do osobe, stvar je ličnosti, odnosno kada će reći da je zadovoljan i lošim uslovima rad jer ima visoku platu, dok će drugi radnik iskazati nezadovoljstvo na uslove rada iako ima visoku platu.

Zadovoljstvo poslom se definiše kao funkcija vrednosti, nešto što zaposleni želi da postigne: ugodan osećaj koji proističe iz saznanja da nečiji posao ispunjava ili omogućuje ispunjenje njegovih poslovnih vrednosti [1].

\section{NAPOMENA:}

Ovaj rad proistekao je iz master rada čiji mentor je bila dr Leposava Grubić Nešić, red.prof.
Kognitivna komponenta podrazumeva ono što čovek veruje da zna o poslu, na osnovu čega gradi svoj lični stav, evalutivna komponenta odnosi se na to koliko volimo ili ne volimo neku stvar ili osobu, a bihejvioristička komponenta sadrži određenu predispoziciju da se deluje u određenom smeru. S obzirom na to da zadovoljstvo poslom predstavlja neki opšti stav pojedinca prema radu, ali i zadovoljstvo prema poslu na osnovu plate, posla samog po sebi, mogućnosti za promociju nadređenih i saradnika [2].

\subsection{Pristupi zadovoljstva poslom}

Tri glavna pristupa zadovoljstva poslom su

Prvi pristup naglašava različite aspekte radne sredine kao uzroke zadovoljstva poslom. Među njima je 5 karakteristika posla Hackmana i Oldhamsa: raznovrsnost veština, identitet zadataka, značajnost zadataka, samostalnost i povratna informacija o ispravnosti obavljenog posla.

Drugi pristup naglašava važnost karakteristika ličnosti u oblikovanju zadovoljstva poslom zaposlenog. U longitudinalnim istraživanjima se utvrdilo da je zadovoljstvo poslom veoma stabilno tokom vremena jer afektivne dispozicije procenjene kod mladih radnika značajno korelirajuj sa zadovoljstvom poslom koje je procenjivano nakon pedeset godina. Kao moguće objašnjenje tih nalaza bilo bi da je afektivna dispozicija povezana sa ,pogledom na svet" određene osobe. Tako ljudi sa negativnim dispozicijama mogu percipirati sve aspekte svog života, uključujući i profesionalni, u lošijem svetlu nego što to čine ljudi sa pozitivnim dispozicijama.

Treći pristup naglašava važnost proučavanja uticaja interakcije između sredine i ličnosti na zadovoljstvo poslom. Istraživanja koja su proučavala korespodenciju između onog što ljudi žele na poslu i onog što imaju nedvosmisleno pokazujuda što je manji raskorak između željenog i ostvarenog to je veće zadovoljstvo poslom [3].

\subsection{Faktori zadovoljstva poslom}

Faktori koji utiču na zadovoljstvo poslom mogu se podeliti u dve grupe:

1. Organizacioni faktori,

2. Individualni faktori.

U okviru organizacionih faktora ubrajamo sistem nagrađivanja, posao sam po sebi, prijatni radni uslovi, kolege na poslu i organizaciona struktura. 
U okviru individualnih faktora ubrajamo sklad ličnih interesovanja i posla, radni staž i starost, pozicija i status, ukupno zadovoljstvo životom [4].

Nagrađivanje zaposlenih predstavlja najkompleksniju aktivnost upravljanja ljudskim resursima, budući da je podjednako važno za sve zaposlene. Ova aktivnost predstavlja jednu od glavnih komponenti ukupnih troškova i osnovni instrument u modifikovanju ponašanja zaposlenih.

Sistem nagrađivanja obuhvata novac, dobra ili usluge koje poslodavac obezbeđuje svojim zaposlenima u zamenu za uloženi rad. Osnovna uloga sistema nagrađivanja u preduzeću jeste da uskladi individualne interese zaposlenih i strategijske ciljeve preduzeća [5].

Sistem nagrađivanja čine dve vrste nagrada:

1. materijalne - koje poslodavac daje zaposlenima su obuhvaćene sistemom zarada

2. nematerijalne nagrade - kao što su na primer poštovanje, izazovan posao i slično. Zbornika u konačnu verziju rada.

\subsection{Efekti zadovoljstva poslom}

Zadovoljstvo poslom može uticati na nivo posvećenosti organizaciji, na fluktuaciju i finansijsku dobit organizacije, ali i na nivo performansi, na spremnost radnika da se uključi u aktivnosti koje su usmerene ka rešavanju problema te na intenzitet napora koje radnik ulaže $u$ obavljanje posla. Ukoliko je radnik zadovoljan onim što radi, onda posao manje doživljava kao rad, a više kao uživanje. Zadovoljstvo poslom utiče na apsentizam (odsustvovanje sa posla), fluktuaciju (dobrovoljno napuštanje posla) i radni učinak zaposlenih [6].

Četiri tipa reakcije zaposlenog na nezdovoljstvo poslom kojim se bavi:

Napuštanje - aktivna destruktivna reakcija, odlazak iz preduzeća zbog nezadovoljstva

Zanemarivanje - pasivno puštanje da se situacija pogoršava, povećava se odsustvovanje sa posla, redukuje zalaganje, povećava škart.

Protestvovanje - aktivno konstruktivno zalaganje da se otklone uzroci nezadovoljstva

Lojalnost - pasivno, kontruktivno čekanje da se stvari poprave [7].

\subsection{Posledice (ne)zadovoljstva poslom}

Odsustvovanje sa posla (apsentizam)

Veliki broj teorijskih izvora navodi sledećih pet razloga odsustvovanja sa posla:

1. Sadržaj i kontekst posla - pod ovim podrazumevamo faktore kao što su dizajn posla, rad pod pritiskom, rad u grupi, menadžerski stil, organizacione politike i procedure, priroda i vrsta ugovora (posao na određeno ili neodređeno vreme), organizacione norme kojima se vrednuje redovno dolaženje na posao.

2. Radne vrednosti - stepen odgovornosti koji pojedinac oseća prema poslu, klijentima, menadžmentu, radnoj grupi, i uopšte individualna radna etika.
3. Karakteristike zaposlenog - pod ovim podrazumevamo faktore kao što su starosno doba, obrazovanje, porodični status, karakteristike ličnosti.

4. Pritisak da se redovno dolazi na posao - ovde se misli na faktore kao što su ekonomski i tržišni uslovi, platna politika kompanije, disciplinske politike u kompaniji, norme i dinamika radne grupe, nivo organizacione posvećenosti.

5. Sposobnosti dolaska na posao - ovde se podrazumevaju faktori kao što su bolest (kratkotrajna ili dugotrajna), nesrećni slučajevi (na poslu ili van posla), porodična odgovornost i posvećenost, teškoće u prevozu [8].

6. Fluktuacija. Fluktuacija predstavlja svaki trajan odlazak zaposlenih iz organizacije.

\subsection{Merenje zadovoljstva poslom}

Istraživanje zadovoljstva poslom obuhvata i istraživanje pouzdanih i validnih instrumenata kojima se sistematski meri zadovoljstvo poslom. Merenje zadovoljstva poslom je ustvari merenje reakcija na posao. Do sada je u stručnoj literaturi razvijeno nekoliko korisnih tehnika za merenje zadovoljstva poslom, uključujući:

1. Rejting skale i upitnike,

2. Kritične incidente,

3. Intervjui i sastanci konfrontacije [9].

\section{PROBLEM ISTRAŽIVANJA}

Problem istraživanja je utvrditi da li zaposleni u proizvodnji i zaposleni iz IT sektora koji rade u različitim programerskim firmama u Novom Sadu imaju pozitivne ili negativne stavove o različitim aspektima posla, odnosno da li su zaposleni zadovoljni poslom.

\section{PREDMET ISTRAŽIVANJA}

Predmet ovog istraživanja jeste da se kroz ankete koje su radnici popunili uvidi koliko su oni zadovolnji pojedinim segmentom posla, kako bi menadžer spram ovih rezultata imao uvid u mišljenje zaposlenih. Rezultati ankete će pomoći menadžerima da reše problem tako što će predložiti mere kojima bi se popravilo zadovoljstvo poslom. Ukoliko se na vreme popravi zadovoljstvo poslom, tada će i radnici biti motivisani za rad.

\section{CILJ ISTRAŽIVANJA}

Cilj istraživanje je da se otkrije koliko su zaposleni zadovoljni pojedinačnim aspektom posla, kako bi rukovodsvo zaposlenih na vreme popravilo zadovoljstvo i motivisalo zaposlene, kako bi zaposleni mogli neometano da ispunjavaju svoje poslove i zadatke.

\subsection{Društveni cilj istraživanja}

Utvrđivanje zadovoljstva pojedinačnim aspektima posla, ispitati i utvrditi načine za ostvarivanje zadovoljstva posla, primeniti načine i rešenjapovećanja zadovoljstva posla. 


\subsection{Naučni cilj istraživannja}

Utvrditi nivo zadovoljstva zaposlenih i ispitati zbog čega dolazi do nezadovoljstva poslom.

\subsection{Hipoteze istraživanja} Opšta hipoteza (H1)

•H1- Postoji razlika u nivou zadovoljstva poslom zaposlenih u indrustrijskoj proizvodnji i IT sektoru.

\section{Pojedinačne hipoteze}

•H1-1 Zaposleni su zadovoljni mogućnošću da se stalno nešto radi (aktivnost).

-H1-2 Zaposleni su zadovoljni šansom da rade samostalno (nezavisnost).

•H1-3 Zaposleni su zadovoljni šansom da s vremena na vreme rade različite stvari (varijabilnost).

-H1-4 Zaposleni su zadovoljni šansom da budu „neko i nešto" u zajednici (društveni status).

-H1-5 Zaposleni su zadovoljni načinom na koji se šef odnosi prema zaposlenima (nadgledanje i kontrola).

•H1-6 Zaposleni su zadovoljni stručnošću u donošenju odluka onog koji ih nadgleda (nadgledanje i kontrola).

•H1-7 Zaposleni su zadovoljni mogućnošću da rade stvari koje nisu protiv njihove savesti (moralne vrednosti).

•H1-8 Zaposleni su zadovoljni time što posao pruža stalno zaposlenje (bezbednost).

•H1-9 Zaposleni su zadovoljni šansom da učine nešto za druge ljude (društvena služba).

-H1-10 Zaposleni su zadovoljni šansom da ljudima govore šta da rade (posedovanje autoriteta).

-H1-11 Zaposleni su zadovoljni šansom da rade nešto gde upotrebljavaju svoje sposobnosti (korisnost sposobnosti).

•H1-12 Zaposleni su zadovoljni načinom na koji se sprovode pravila/poslovna politika firme (politika i praksa kompanije).

-H1-13 Zaposleni su zadovoljni visinomplate i koliko mnogo rade (kompenzacija).

•H1-14 Zaposleni su zadovoljni šansom da napreduju na poslu (unapređenje).

-H1-15 Zaposleni su zadovoljni slobodom da koriste svoje rasuđivanje (odgovornost).

-H1-16 Zaposleni su zadovoljni šansom da probaju da primene svoje metode rada na poslu (kreativnost).

•H1-17 Zaposleni su zadovoljni uslovima na radu (radni uslovi).

•H1-18 Zaposleni su zadovoljni kako se kolege međusobno slažu (saradnici).

•H1-19 Zaposleni su zadovoljni pohvalama koje dobijaju za dobro urađen posao (prepoznavanje).

•H1-20 Zaposleni su zadovoljni ispunjenošću koju im pruža posao (postignuće).

\section{NAČIN ISTRAŽIVANJA I REZULTATI ISTRAŽIVANJA}

Istraživanje zadovoljstva poslom je sprovedeno $u$ dve različite godine i u dve različite industrije.

Prvo istraživanje sprovedeno je u januaru 2020. među radnicima u proizvodnji, u periodu od 8. 1.2020.10.1.2020. godine.

Istraživanje je izvršeno na teriotoriji grada Novog Sada.

Istraživanje je interdisciplinarnog tipa i obuhvata više naučnih disciplina, zasnovano je na menadžmentu ljudskih resursa. Trideset dobrovoljaca, zaposlenih u sektoru montaže je odgovorilo na pet različitih upitnika. Upitnici su bili u štampanoj formi, radnici su ručno popunili upitnik. Upitnik koji su radnici popunili je anoniman, za potrebe ovog rada iskorišćena su tri upitnika.

Drugo istraživanje je sprovedeno u maju 2021. godine, u tri različite programerske kompanije koje se bave izradom veb sajtova, softverima i kreiranjem aplikacija. Istraživanje je izvršeno na teritoriji grada Novog Sada. Istraživanje je interdisciplinarnog tipa i obuhvata više naučnih disciplina, zasnovano je na menadžmentu ljudskih resursa. Trideset dobrovoljaca, IT stručnjaka zaposleni u okviru IT struke odgovorilo je na pitanja iz upitnika, upitnik je poslat u štampanoj formi. Upitnik koji su radnici popunili je anoniman, za potrebe ovog rada iskorišćena su tri upitnika.

Kroz svako pojedinačno pitanje možemo videti da su zaposleni u IT sektoru zadovoljniji poslom nego zaposleni $\mathrm{u}$ proizvodnji, zaposleni u IT sektoru su na petnaest pitanja imali veći zbir pozitivnih odgovora nego zaposleni u proizvodnji koji su imali ukupno pet odgovora. Opšta hipoteza u potpunosti potvrđena odnosno da postoji razlika u nivou zadovoljstva poslom kod zaposlenih $\mathrm{u}$ industrijskoj proizvodnji i IT sektoru kod svih zaposlenih dok se pojedinačne hipoteze razlikuju. Rezultati zaposlenih u proizvodnji pokazuju da su četiri hipoteze opovrgnute odnosno da radnici time nisu zadovoljni, to su sledeće hipoteze:

1.H1-6 Zaposleni su zadovoljni stručnošću u donošenju odluka onog koji ih nadgleda (nadgledanje i kontrola).

2.H1-10 Zaposleni su zadovoljni šansom da ljudima govore šta da rade (posedovanje autoriteta).

3.H1-12 Zaposleni su zadovoljni načinom na koji se sprovode pravila/poslovna politika firme (politika i praksa kompanije).

4.H1-19 Zaposleni su zadovoljni pohvalama koje dobijaju za dobro urađen posao (prepoznavanje).

Kod jedne hipoteze zaposleni imaju podeljeno mišljenje:

H1-14 Zaposleni su zadovoljni šansom da napreduju na poslu (unapređenje).

Zaposleni u IT sektoru su u potpunosti potvrdili svih dvadeset hipoteza, odnosno dali su pozitivan odgovor na dvadeset pitanja.

Poređenjem dobijen rezultata možemo reći da su zaposleni u proizvodnji manje zadovoljni poslom jer imaju četiri hipoteze koje su opovrgnute, dok su kod zaposlenih u IT sektoru sve potvrđene.

\section{PREDLOZI UNAPREĐENJA}

1. Poboljšati korporativnu komunikaciju

Pitati zaposlene za mišljenje, kako bi zaposleni stekli 
utisak da su pažljivo saslušani, upoznati zaposlene sa poslovnim rezultatima preduzeća, zaposleni ne treba da budu samo zainteresovani za svoj rezultat, već i za rezultat kompanije, upoznati zaposlene sa problemima sa kojima se preduzeće suočava i proslediti informaciju o radu drugih sektora.

\section{Poboljšanje radnih uslova}

Neophodno je radne uslove prilagoditi radniku, jer će na taj način radnik kvalitetnije obavljati svoj posao, neki od predloga kako mogu da se poboljšaju radni uslov su poštovanje pauze za ručak, prostor za odmor unutar poslovne zgrade, obezbediti parking prostor

\section{Organizacija posla i mogućnosti napredovanja}

4. Međuljudski odnosi i lojalnost

5. Zadovoljstvo radnim mestom, sigurnost radnog mesta.

Sigurnost radnog mesta je nešto što se nikada do kraja ne može zagarantovati, ali je izuzetno važno da, ukoliko je kompanija u mogućnosti to da obezbedi svojim zaposlenima, da se postara da oni to i osete. A kada i dođe do potrebe za promenom broja zaposlenih, da kompanija upravlja tim promenama na način da se obazire na dobrobit zaposlenih i što većem broju zaposlenih obezbedi koliko-toliko sigurnu budućnost.

\section{ZAKLJUČAK}

Čovek je kompleksno biće i napori za zadovoljenje osnovnih egzistencijalnih potreba samo su jedan i to najznačajniji segment njegovor angažovanja na radnom mestu. Ako posmatramo radnike u proizvodnji dodatno bi povećali zadovoljstvo poslom kod radnika na montaži ako bi im dodatno povećali platu (bez obzira što su oni zadovoljni platom), ako bi im se jednom godišnje dao bonus $\mathrm{u}$ vidu dodatne plate, zadovoljstvo poslom bi se povećalo i kada bi radnici ostvarili bolji odnos sa nadređenim, organizovati sastanak gde bi zaposleni izneli svoje probleme kako bi se sve nesuglasice rešile, obučiti rukovodioca, tek tada bi zaposleni sa svima u organizaciji imali korektan odnos.

Posmatrajući zaposlene u IT sektoru dodatno bi povećali zadovoljstvo nagrađivanjem, radnim prostorom za odmor, prostorom gde radnici mogu da ustanu prošetaju, odigraju partiju pikada ili stonog tenisa, za žene bi izuzetno bilo kada bi se firme stavile na takvu lokaciju da je u blizini vrtić ili čak da vrtić bude u samoj firmi za zaposlene.

Posmatrajući proizvodnju i IT industriju, dve potpuno različite grane shvatila sam da su zaposleni zadovoljni, da su oni pre svega potpuno različiti i da žele i rade potpuno različite stvar, različite nagrade ih čine srećnim i zadovoljnim, ali ono najvažnije jeste da su i jedni i drugi zadovoljni i da obavljaju posao koji im prija i koji ih ispunjava što su rezultati i pokazali.
Svaka industrija je za sebe, tipovi ličnosti su različiti, ovde smo baš to i videli, da nije bitno kojoj industriji pripadate, koje je vaše obrazovanje, koji posao obavljate bitno je da budete zadovoljni i ispunjeni svakim segmentom posla.

\section{LITERATURA}

[1] Noe, R., Hollenbeck, J., Gerhart, B. i Wright, P. (2005) „Menadžment ljudskih potencijala“. III izdanje. Zagreb: Zagrebačka škola ekonomije i menadžmenta.

[2] Janićijević, N.(2008), Organizaciono ponašanje, Data status, Beograd.

[3] Katić, Ivana. (2017),Upravljanje karijerom“ Novi Sad: Univerzitet u Novom Sadu, Fakultet tehničkih nauka.

[4] Grubić-Nešić, L.(2014). „Razvoj ljudskih resursa"Novi Sad: Fakultet tehničkih nauka.

[5] Dimitrijević., Bojana, (2017). „Planiranje ljudskih resursa, regrutovanje i selekcija kandidata"Bar: Fakultet za poslovni menadžment.

[6] Janjić, Ivana Srđan., Ilić, Đurđijana, Dejan., (2019), „Zadovoljstvo poslom kao merilo subjektivnog uspeha u karijeri“", Naučno stručni časopis Visoke škole za poslovnu ekonomiju i preduzetništvo iz Beograda.

[7] Robbins, P.S., (2001) „Organizational Behavior”, New Jersey, Prentice Hall International Ed.

[8] Đorđević Boljanović, J., Pavić, Ž., (2011) „Osnove menadžmenta ljudskih resursa“, Beograd: Univerzitet Singidunum.

[9] J. Greenberg. A. B. Baron (1998.). „Ponašanje u organizacijama“, Želnid, Beograd.

\section{Kratka biografija:}

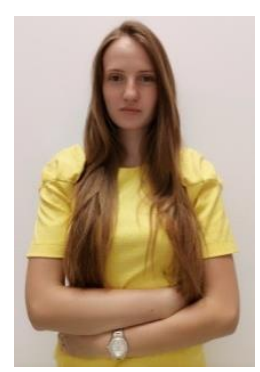

Jelena Lukić rođena je u Novom Sadu, 19. 12. 1997. godine. Master rad na Fakultetu tehničkih nauka na smeru Menadžment ljudskih resursa odbranila je2021. godine. 